\title{
Student Perception of Traditional English Teaching Methods (CLT approach) and Comparison to Modern Methods (Using Technology)
}

\author{
Feras Mohammed AL-Madani \\ Faculty of Education and Arts, Northern Border University, Saudi Arabia \\ Received: November 23, 2020. Revised: March 3, 2021. Accepted: March 9, 2021.
} Published: March 12, 2021.

\begin{abstract}
This study aimed to assess the perception of students regarding traditionally used CLT approach for teaching English language and its comparison to modern teaching methods based on technology. Survey was carried out using a quantitative analysis on 200 students of English language teaching institutes that are currently using CLT approach. Pre and post responses survey was carried out wherein their perspectives were assessed before and after exposure to technology-based ELT methods. Analysis was carried out using Wilcoxin test which revealed the impact of modern technological tools used in language teaching, such as, video conferencing, audio CDs, online oral versions, text-to-speech synthesis, interactive books, digital game-based learning and computer assisted language learning (CALL).
\end{abstract}

Keywords - Communicative language teaching, ELT methods, English language, Modern methods

\section{INTRODUCTION}

A. Overview of traditional teaching methods for languages Communicative language teaching approach (CLT approach)

$\mathrm{C}$ ommunicative Language Teaching (CLT) was proposed in 1970, and since then it had been considered as a major foreign language teaching/learning technique across the world. This method is an alternative to the more prominently used method of memorization and grammar learning methods, which has been popular in the last century. For the ease of learning a foreign language, educators developed various new methods that were considerably more effective and had more theory than the methods used by their precursors, that led to the development of CLT [1]. One of the contributing factors in development of "communicative language teaching" was dissatisfaction with previous learning methods, which did not combine non-communicative and communicative learning activities. At first, CLT was identified as a 'British Tradition' [2], as it established by linguists of British origin.

In 1980's many linguists and educators had added their own approaches to this method, all focused on teaching a foreign language. With time, CLT was altered to cater ever-changing needs of students and educators and became a hybrid approach, which includes, repetitive learning, grammatical exercises and communication exercises. CLT method is focused on communication activities as a basis for learning activities between learner and teacher, the basic concept here is to teach usage of language for wide range of purposes. This method focuses on collaborative meaning creation, purposeful language interaction, feedback from learners and experimentation with language usage. Under this method, the language learning is based on the requirement of learner; it includes understanding and producing different kinds of texts in various contexts, such as, spoken conversation, informal writing and formal writing. It aids learner in maintaining conversation despite having limited knowledge of the language [3],[4] .

B. Impact of technology on the language teaching methods

Advancement in technology has affected all sectors of life and benefit to it, the impact of technology had revolutionized education sector. In general, language instructors/educators had faced the lack of motivation, lack of engagement and less student involvement in the teaching method used, use of different technological activities can aid in overcoming such challenges. There are mainly four kinds of skills involved in learning any language namely, listening, speaking, reading and writing. Listening is the process of recognizing and understanding the speaker's speech including accent, pronunciation, vocabulary and grammar whilst comprehending the meaning [5]. There are many innovative techniques available nowadays to enhance and support listening skills and capabilities of learner. First is use of computer, which enhances understanding of the learner by reinforcing information and concepts as compared to 
traditional methods. Second is listening to TV and radio broadcast, that aids in improving communication capabilities of the student and develop understanding ability [6].

Next skill is reading, which aids in improving vocabulary of the learner. Some of the technological tools aids in improving reading ability of learner. Computer/Mobile based- reading programs/application are used for increasing the interest of learner and improve their vocabulary. Use of internet-based reading programs can raise the interest of reading for learners using simple and easy means to understand text. Many multimedia software that consists of text, audio, graphics, animation, video and such, increase comprehension of the learner. In addition to this use of electronic dictionaries, newspapers, magazines, encyclopedias add to the knowledge [7], [8]. Next skill is speaking i.e., ability to convey desired meaning in the learning language. Speaking skills can be enhanced using multiple technological applications. First is using voice chatting based on internet that provide good platform for practicing. Second is Voice Synthesis Programs that enhances speaking capability by strengthening pronunciation and vocabulary. Last is Writing skill, ability to write meaningful sentences with proper grammatical structure. Use of computer and graphical software had make writing more enjoyable and easier. Programs like MS Word, improves grammar skills of the learner [9] .

\section{AIM OF THE STUDY}

The main aim of this study is to analyze perception of students on the traditionally used CLT approach for teaching English language. For this, the study will compare the modern technology-based language learning methods with traditional CLT approach for learning English language

\section{CENTRAL RESEARCH QUESTION}

Based on aim of this research study, the central research question is as follows:

What is the perception of students on use of CLT approach for learning English language compared with technology based modern methods?

\section{LITERATURE REVIEW}

\section{A. Rise of information technology role in Education}

Across the globe with the development of technologies and focus on economic development, there has been shift in focus of government and the countries towards improving the quality of education. Education has become an essential component of national policies for enabling economic growth and high skilled workforce [10]. In today's digital economy, intellectual space-based models are formulated for enabling innovative modernization representation in the knowledge representation. Knowledge based processes have been developed with systematization of areas like innovation and project management, mathematical modelling, or organizational design wherein new information systems in order to solve the learning based problems in the traditional education models [11]. Bringing in revolutionary changes in education, modern technologies have opened the gates for education even for physically disabled, learning disabled or visually and hearing impaired. Promoting independent learning for students, easier access to information, accessibility, and cooperative learning among students while flexibility of teachers, sharing of expertise, develop professional teaching skills, and interactive medium of teaching for teachers, information technology promotes knowledge sharing throughout world [12].

\section{B. Diminishing use of CLT approach in language teaching}

With the development of Task-Based Language Teaching (TBLT), the use of communicative language-based teaching (CLT) had diminished [13]. These new techniques have their own identity and demonstrate superiority over traditional methods. CLT does not pay attention to context of teaching and learning, instead it focuses on fluency not on accuracy. Without focus on error reduction in the existing CLT approach, there is more cases of incorrect and incoherent learning. Further, lack of focus on oral and writing skills, low proficiency of language and lack of participation on student' part tends to reduce the effectiveness of CLT and diminishes its usage. Other than this, CLT also does not focus on the context of the learner, with this approach students are not provided with opportunities to express their views and ideas [14]. Educator/trainer act as an adviser with CLT approach as opposed to a facilitator. As CLT have limited linguistic scope and lack in forming cognitive methods and learning tactics, thus, this language teaching approach does not fulfil requirement of the present times learners [2]. . In addition, for more adequate learning, it is necessary to give equal importance to accuracy and fluency, however, CLT approach due to having not much value to these aspects tend to put a lot of pressure on educator. Thus, although CLT method is more time efficient than existing more traditional approaches, but still having the overlook on grammar acquisition and proper understanding of sentence structure, there is reduction in preference for this method.

\section{Modern technology-based language teaching methods}

Use of technology in learning language has become a trend nowadays; students have high-level acceptability for such techniques for enhancing their language skills. With this rising preference to technology, there has been adaptation of modern methods of teaching English language such as language learning web sites, e-dictionaries, and video tutorials in order to provide more efficient learning experience [6]. As classical teaching methods are based mainly on rarely used practice and theory, miss motivation factor and are less exciting, slower way of teaching, and are majorly concentrated on teacher; thus, there is more acceptability of students towards utilization of technology for language skills enhancement. With the use of language supports, learners are encouraged to effectively learn language and improve their skill set [9]. Technology based learning has provided easier access and mobility to 
language learning instructions via Internet. Thus, technological medium for instruction process had become a necessity nowadays, it had become essential for learning language skills including both theory and practice [15]. Some of the majorly used technological methods are as follows:

1) Video conferencing

Video-conferencing is regarded as a substitute for face-toface learning for remote users foreign language learning with the benefit of having the facility to having productive combination of working alone and collaboratively [16]. Videoconferencing is a tool for learning English as foreign language supporting development of linguistic competence. The video conferencing method is more effective than the traditional learning mechanism with the creation of diversity opportunity for students by making it possible to learn with other students of different cultures. Though videoconferencing helps in intercultural communication and schema competence, discourse competence, communicative and pragmatic competence, and self-study strategic competence but videoconferencing effectiveness leads to challenges like practical, technical, linguistic, and communicative problems [17]. Now-a-days adoption of video conferencing as a teaching/ learning tool for foreign language is taking place across a vast area for language teaching, as this interactive technology had made its mark as collaborative, motivating and effective learning tool [18] .

2) Talking text (like audio CDs, online oral versions, text-to-speech synthesis, interactive books)

Talking text tolls are mostly used in enhancing listening and speaking skills of the language learner. There are majorly three levels of talking text tools, namely, classification of subsyllabic elements, word elements and pronunciation that aids in improving language skill of user [19]. Teaching and learning foreign language assisted by audio cassettes, CDdrivers, DVD-Drivers, and radio broadcast have changed the teaching and interaction dynamics of learner and educator for better [20]. Online oral software aids students in dealing with anxiety related to learning foreign language and help them achieve their learning goals via an interactive online environment. Text-to-Speech synthesizers (TTS) and speech recognition tools have potential to improve writing skills, aids in vocabulary building, and improves pronunciation and reading skills [15]. Further, TTS systems is effective at various stages of learning as it assists improving speech ability, cognitive processing, articulation and more. Instructive use of TTS is noted to instill a positive attitude in students towards learning and was noted to more accurate and comprehensible [21].

\section{3) Digital game-based learning}

In the past decade, digital game-based learning approach had gained tremendous popularity and its application in various teaching programs have risen significantly. Drill and practice games are considered as good learning tool by many researchers. Digital game based learnings positive impact of mobile and computer games on learning, as it enhances attention of the learner [22]. Online games provide an engaging learning experience for learners, immediate feedback from game, clearly defined goals and targets are designed to enhance skills of the learner. Educational games contribute in maximizing learning impact, as the learner keeps playing (practicing) until high score is achieved [23]. Further, musical video games could also be used in revising vocabulary for second language [24]. Though, online gaming is used by various learners as a leisure activity but not for educational purposes. However, it has been suggested to promote gamebased learning and have its use as mediation by educators [25].

\section{Computer assisted language learning}

Computer assisted language learning (CALL) is fundamentally sets of instructions that are loaded in computer that is used in language classrooms. It does not refer to typing any worksheet or list for teaching, it refers to an interactive programs that aids in learning [26]. Speech synthesis tools (such as, dictation software) in computer assisted learning of languages helps learners to focus on tutorial software for acquiring linguistic knowledge and improving language skill [27]. The usage of digital learning materials enhances the learning and teaching experience by providing speed ability and self-study motivation to students. Thus, this technical tool overcomes many shortcoming of conventional language teaching methods, by improving teaching content and increase interest of students for effective learning [26].

\section{Methodology}

Research methodology is a methodical, strategic and scholastically prearranged method for gathering the required data for successful completion of the research study [28] . As the focus is on deriving more information about the traditional and modern English learning methods, explanatory research design would be used wherein having the quantitative assessment of the student's perception, the results would be drawn. The targeted population of the study is the students studying in English language teaching institutes located in Saudi Arabia. Herein, using the simple random sampling method, the respondents were selected from 10 English language teaching institutes that were using CLT approach. The selection criteria included students studying in different grades, having completed at least 1-month period of study with the institute. Sample size for the study is computed using Cochran's formula at $95 \%$ level of confidence interval i.e.

$$
n=\frac{z^{2} * p *(1-p)}{e^{2}}
$$

$n=\frac{1.96^{2} * 0.85 *(1-0.15)}{0.05^{2}}=195.9216 \approx 196$ approx

wherein,

n: sample size

$\mathrm{z}$ : confidence level $\mathrm{z}$ score value (i.e. 1.96 at $95 \%$ confidence level)

$\mathrm{p}$ : proportion of population participating in the study $(85 \%$ or 0.85$)$

e: desired level of precision or margin of error (i.e. 0.05) 
As the sample size derived is 196 approximately thus for having precise sample size, 200 respondents were considered as the sample for study. Herein a close-ended structured questionnaire was prepared for collection of these respondents perception consisting of demographic questions (questions about demographical characteristics), background section (question on the knowledge level of respondents about the English learning methods), and inferential section (statements for examining the hypothesis of study). Initially the institutes were contacted for organizing the survey via email and having their confirmation derivation, they were explained about the purpose of study and relevance of adopting ELT approach over CLT via telephone. 200 students (20 from each institute) were selected randomly and via a session explained about the study, aim and significance of study via face-to-face interaction along with describing about the technology-based ELT method that they will be exposed to. After this interactive session within 2 days the examination began, and the aim was to expose students to new approach for atleast 3 weeks. Students were asked to fill the questionnaire pre and post training via Google forms. Lastly, using Chi-square, t-test, and Wilcoxon test the analysis of perception were done. Herein SPSS was used as tool of analysis and as the results of the study were determined after statistical analysis and were kept free from biasness, thus they are reliable, valid, and ethical.

\section{DATA ANALYSIS}

\section{A. Descriptive Analysis}

Descriptive statistical analysis is used to understand the student's perception on using technology for ELT. Graphical representations are also included to representing results to increase the understanding of data analysis presented. The gender and age distribution of students is presented in figure 1, it was noted that $66 \%$ of students were male and remaining were female. Majority of students around $46 \%$ were of age group 21-30 years, $38.5 \%$ were from age group $31-40$ years, $10.5 \%$ were from age group $41-50$ years and only $5 \%$ were above 50 years.

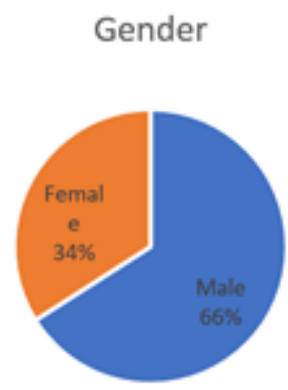

(a)

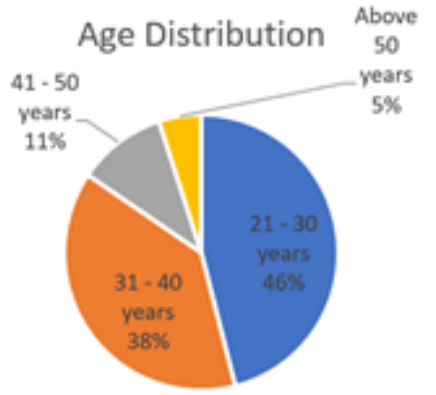

(b)
Fig. 1: Distribution for gender and age of participants/students.

Distribution for educational qualification and period of studying English language is presented in figure 2, it was noted majority of students surveyed were graduate i.e., almost
$44.5 \%$, around $26 \%$ were intermediate, $13.5 \%$ were high school passed, $10.5 \%$ were below high school and around $5.5 \%$ were post-graduates. The distribution for period of studying English language, around $42.5 \%$ of the surveyed students were studying English language for 5-10 months, $39 \%$ were studying it for $10-15$ months, $7.5 \%$ were studying it for less than 5 months, $6.5 \%$ were studying for 15-20 months and only $5.5 \%$ were studying it for over 20 months.

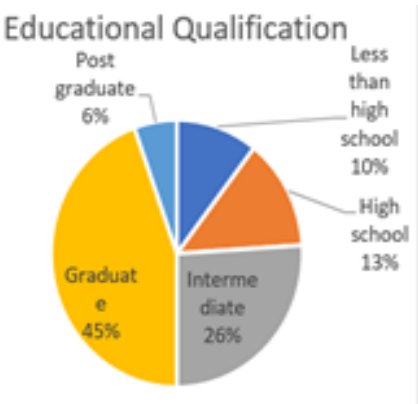

(a)

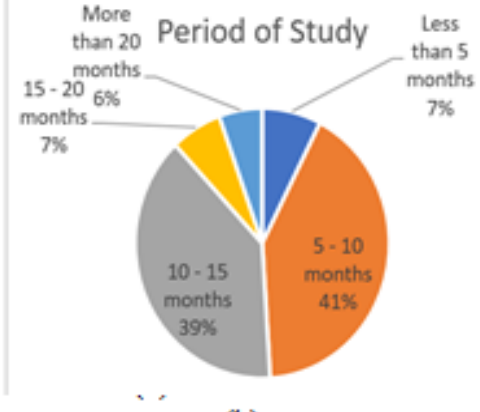

(b)
Fig. 2: Distribution for educational qualification and period of studying English language.

Students were asked whether English language is required in their lives, majority $86.5 \%$ of the participating student have responded in positive, $4 \%$ responded in negative and $9.5 \%$ were indecisive. This distribution is depicted in figure 3 , it showcases the growing need to learn English language in present times.

Distribution for need of English language learning

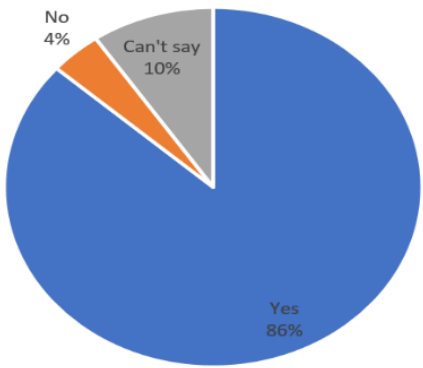

Fig. 3: Distribution for need of English language learning

Figure 4 depicts distribution for initial proficiency level in English language of the surveyed students. $24.5 \%$ of the students admitted to have very good command on English language initially, $5.5 \%$ of the students revealed that they had good command on English language, $20 \%$ of the students admitted that they were average initially, only $2 \%$ perceived their initial language skill as extremely bad and a majority of $48 \%$ of students admitted to be bad at English language initially. 


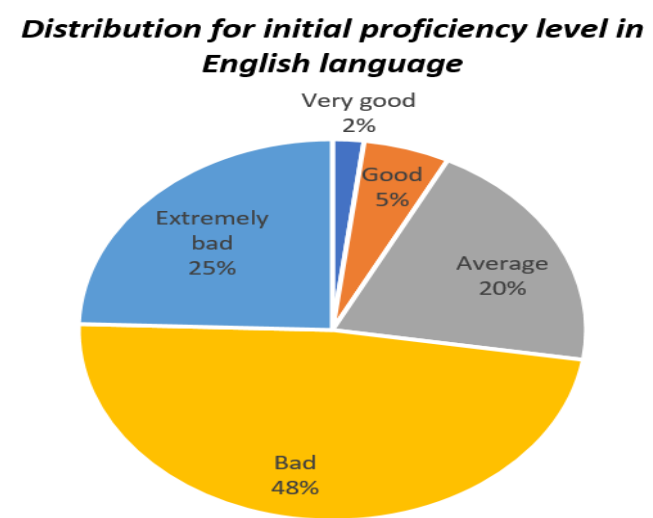

Fig. 4: Distribution for initial proficiency level in English language

Figure 5 demonstrate the distribution for frequency of English language classes attended by the participating students. Majority of $45 \%$ of the students attend weekend classes, $34.5 \%$ attend class once a week, $13 \%$ had classes on weekdays and $8.5 \%$ have class every day.

\section{Distribution for frequency of English language classes}

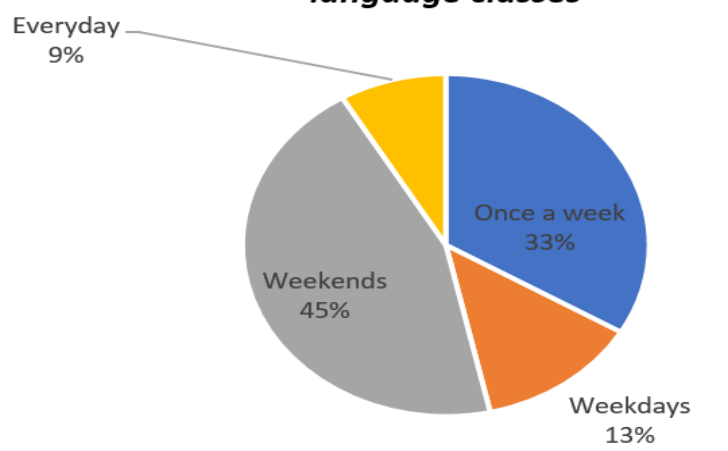

Fig. 5: Distribution for frequency of English language classes

\begin{tabular}{l|r|r|r|r|r}
\hline & \multicolumn{1}{c|}{ N } & \multicolumn{1}{c|}{ Mean } & $\begin{array}{c}\text { Std. } \\
\text { Deviation }\end{array}$ & Minimum & Maximum \\
\hline \multicolumn{5}{|c|}{ Pre-Analysis } \\
\hline $\begin{array}{l}\text { Reading } \\
\text { Skills }\end{array}$ & 200 & 2.78 & 0.751 & 1 & 5 \\
\hline $\begin{array}{l}\text { Listening } \\
\text { Skills }\end{array}$ & 200 & 2.67 & 0.725 & 1 & 4 \\
\hline $\begin{array}{l}\text { Speaking } \\
\text { Skills }\end{array}$ & 200 & 2.74 & 0.778 & 1 & 5 \\
\hline $\begin{array}{l}\text { Writing } \\
\text { Skills }\end{array}$ & 200 & 2.64 & 0.695 & 1 & 4 \\
\hline $\begin{array}{l}\text { Reading } \\
\text { Skills }\end{array}$ & 200 & 3.74 & 0.804 & 2 & 5 \\
\hline $\begin{array}{l}\text { Listening } \\
\text { Skills }\end{array}$ & 200 & 3.69 & 0.631 & 2 & 5 \\
\hline $\begin{array}{l}\text { Speaking } \\
\text { Skills }\end{array}$ & 200 & 4 & 0.799 & 2 & 5 \\
\hline $\begin{array}{l}\text { Writing } \\
\text { Skills }\end{array}$ & 200 & 3.94 & 0.796 & 1 & 5 \\
\hline
\end{tabular}

Table I: Descriptive pre and post analysis 1- Extremely Bad; 2- Bad; 3- Average; 4-Good; 5-Excellent

During pre-analysis, the students were asked to rate their language skill set on the scale of 1 to 5 . The first was reading skill, the mean for the rating was calculated to be 2.78 , indicating majority of student either considered their skill as average or bad. The second was reading skill, the mean for the rating was calculated to be 2.67 , third was speaking skill, the mean for the rating was calculated to be 2.74 and last was writing skill, the mean for the rating was calculated to be 2.64, all indicating towards average or bad language skill.

During post-analysis, again students were asked to rate their language skill set on the scale of 1 to 5 . For reading skill, the mean was calculated to be 3.74 , for reading skill, the mean was calculated to be 3.69 , for writing skill, the mean was calculated to be 3.94 , indicating the majority students have marked their skill as average or good. For speaking skill, the mean calculated to be 4 , indicating towards improved overall performance to good.

\section{B. Chi-Square Test}

Chi-square test herein is used in order to compare the relationship between the language skills of individuals and the learning approaches. Herein, comparison of the pre and post test results for the reading, language, speaking, and writing skills is done in order to support the English language teachings. Results of the analysis is shown in below table

\begin{tabular}{|c|c|c|c|}
\hline \multicolumn{2}{|c|}{ Language Skills } & CLT & $\begin{array}{c}\text { ELT post } \\
\text { CLT }\end{array}$ \\
\hline \multirow{5}{*}{ Reading Skills } & Strongly Disagree & 5 & 0 \\
\hline & Disagree & 66 & 12 \\
\hline & Neutral & 99 & 61 \\
\hline & Agree & 28 & 94 \\
\hline & Strongly Agree & 2 & 33 \\
\hline \multirow{5}{*}{ Listening Skills } & Strongly Disagree & 8 & 0 \\
\hline & Disagree & 73 & 4 \\
\hline & Neutral & 97 & 69 \\
\hline & Agree & 22 & 113 \\
\hline & Strongly Agree & 0 & 14 \\
\hline \multirow{5}{*}{ Speaking Skills } & Strongly Disagree & 8 & 0 \\
\hline & Disagree & 67 & 6 \\
\hline & Neutral & 96 & 46 \\
\hline & Agree & 27 & 91 \\
\hline & Strongly Agree & 2 & 57 \\
\hline \multirow{5}{*}{ Writing Skills } & Strongly Disagree & 7 & 1 \\
\hline & Disagree & 76 & 8 \\
\hline & Neutral & 99 & 40 \\
\hline & Agree & 18 & 105 \\
\hline & Strongly Agree & 0 & 46 \\
\hline
\end{tabular}

Table II: Chi-square test for language skills relationship pre and post exposure to technology-based teaching/learning aids had on student's skill 
Above table shows most of the respondents agree with the aspect that ELT post traditional approach has improved their language skills i.e. 127 respondents support the contribution of modern technology based approach in reading and language skills, 148 students accept that technology based approach has improved speaking skills compared to CLT approach, and 151 respondents accept that writing skills are improved with the provision of post-CLT approach in English learning institutions. Further, the linkage of the language skills with the learning approach is shown in below table

\begin{tabular}{|l|r|r|}
\hline Language skills & Chi-square value & Significance \\
\hline Reading skills & 114.57 & 0 \\
\hline Listening skills & 149.9 & 0 \\
\hline Speaking skills & 162.56 & 0 \\
\hline Writing skills & 192.13 & 0 \\
\hline
\end{tabular}

Table III: Chi-square test

As the significance value for all the variables is less than 0.05 i.e. $(0.00<0.05)$, thus the hypothesis of having no relationship between the language skills and learning approach is rejected. Mutambik supported these results with stating that usage of technology in the learning like E-learning in studying English tends to contribute in form of promoting key learning skills, flexible learning, interactive learning, and independent learning [28].Thus, having the change in teaching/learning approach and provision of technology in teaching contributes in having better learning experience.

\section{Independent Sample T-test}

Independent sample t-test herein helps in comparing the learning experience of students in both CLT and modern technology approach thus herein the assessment of student's perception is done. Results of the analysis is shown in below table

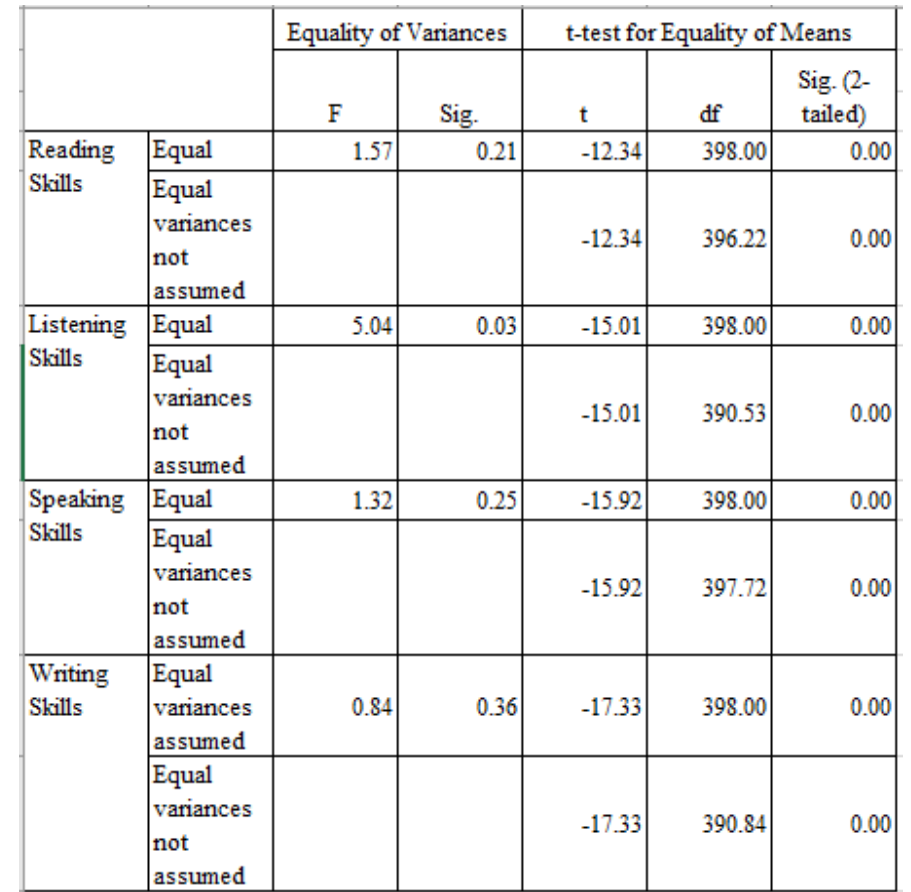

Table IV: Independent Sample T-test for language skills relationship pre and post exposure to technology-based teaching/learning aids had on student's skill

Above table shows that the significance value for Levene's equality of variance test is less than 0.05 for only listening skills, thus there is high variability in listening skills dataset but for reading, speaking, and writing skills; there is presence of consistency in dataset. Further, having the comparison of the learning approach showed that as significance value for all variables is less than 0.05 , thus the null hypothesis of having no relationship between Pre and Posttest is rejected showing variation in the language skills of individuals as the learning approach in the English learning institutions changes. Mahboob and Tilakaratna assessed the English language teaching policies and determined that ELT techniques tend to provide the opportunity of safeguarding against development policy, helps in alignment of approaches to the learning, making learning experience more transparent, and empowerment of students and teachers via collaborative and evidence based research [29]. Thus, change of learning approaches from classical to modern one has influenced the language skills of students with creation of possibility of having improved learning experience.

\section{Wilcoxon Analysis}

The Wilcoxon Signed Ranks test was used in this research study for observing the differences between the samples collected pre- and post-exposure to technology-based teaching/learning aids in English language teaching from students' perspective. 
INTERNATIONAL JOURNAL OF EDUCATION AND INFORMATION TECHNOLOGIES

\begin{tabular}{|c|c|c|c|c|}
\hline \multicolumn{5}{|c|}{ Ranks } \\
\hline \multirow{5}{*}{$\begin{array}{l}\text { Reading Skills - } \\
\text { Reading Skills }\end{array}$} & & $\mathrm{N}$ & $\begin{array}{l}\text { Mean } \\
\text { Rank }\end{array}$ & $\begin{array}{l}\text { Sum of } \\
\text { Ranks }\end{array}$ \\
\hline & $\begin{array}{l}\text { Ne gative } \\
\text { Ranks }\end{array}$ & $0^{2}$ & 0.00 & 0.00 \\
\hline & $\begin{array}{l}\text { Positive } \\
\text { Ranks }\end{array}$ & $125^{\circ}$ & 63.00 & 7875.00 \\
\hline & Ties & $75^{\circ}$ & & \\
\hline & Tota1 & 200 & & \\
\hline \multirow[t]{4}{*}{$\begin{array}{l}\text { Listening Skitls - } \\
\text { Listening Skills }\end{array}$} & $\begin{array}{l}\text { Negative } \\
\text { Ranks }\end{array}$ & $0^{4}$ & 0.00 & 0.00 \\
\hline & $\begin{array}{l}\text { Positive } \\
\text { Ranks }\end{array}$ & $139^{\circ}$ & 70.00 & 9730.00 \\
\hline & Ties & $61^{t}$ & & \\
\hline & Tota1 & 200 & & \\
\hline \multirow[t]{4}{*}{$\begin{array}{l}\text { Speaking Skills - } \\
\text { Speaking Skills }\end{array}$} & $\begin{array}{l}\text { Negative } \\
\text { Ranks }\end{array}$ & $0 z$ & 0.00 & 0.00 \\
\hline & $\begin{array}{l}\text { Positive } \\
\text { Ranks }\end{array}$ & $151^{\mathrm{m}}$ & 76.00 & 11476.00 \\
\hline & Ties & $49^{\circ}$ & & \\
\hline & Tota1 & 200 & & \\
\hline \multirow[t]{4}{*}{$\begin{array}{l}\text { Writing Skills - } \\
\text { Writing Skills }\end{array}$} & $\begin{array}{l}\text { Negative } \\
\text { Ranks }\end{array}$ & $\infty$ & 0.00 & 0.00 \\
\hline & $\begin{array}{l}\text { Positive } \\
\text { Ranks }\end{array}$ & $158^{2}$ & 79.50 & 12561.00 \\
\hline & Ties & $42^{2}$ & & \\
\hline & Tota1 & 200 & & \\
\hline \multicolumn{5}{|c|}{ a. Reading Skitls < Reading Skills } \\
\hline \multicolumn{5}{|c|}{ b. Reading Skills > Reading Skills } \\
\hline \multicolumn{5}{|c|}{ c. Reading Skitls = Reading Skills } \\
\hline \multicolumn{5}{|c|}{ d. Listening Skills < Listening Skills } \\
\hline \multicolumn{5}{|c|}{ e. Listen ing Skills > Listening Skitls } \\
\hline \multicolumn{5}{|c|}{ f. Listening Skills = Listening Skitls } \\
\hline \multicolumn{5}{|c|}{ g. Speaking Skills < Speaking Skills } \\
\hline \multicolumn{5}{|c|}{ h. Speaking Skills > Speaking Skills } \\
\hline \multicolumn{5}{|c|}{ i. Speaking Skills = Speaking Skills } \\
\hline \multicolumn{5}{|c|}{ j. Writing Skills < Writing Skills } \\
\hline k. Writing Skills & Writing Ski & & & \\
\hline
\end{tabular}

Table V: Wilcoxon Analysis for pre and post impact of exposure to technology-based teaching/learning aids had on student's skill

It can be inferred from the above table $\mathrm{V}$ that there is significant impact on language skills of students post exposure to technology as compared to pre-exposure level. It was noted that majority of students (125 students) have noted significant improvement in their reading skill after use of technologybased methods, 75 students have noticed no difference in their reading skills. For listening skills, 161 students have perceived significant improvement and 39 students have noticed no improvement. 151 students have revealed positive impact on their English-speaking skills as compared to 49 students, who were neutral. The last is writing skills, as many as 158 students have noticed improvement as compared to 42 neutral students. There was no negative rank for all the four skill sets.

\begin{tabular}{|c|c|c|c|c|}
\hline \multicolumn{5}{|c|}{ Test Statistics ${ }^{\mathrm{a}}$} \\
\hline & $\begin{array}{l}\text { Reading } \\
\text { Skills - } \\
\text { Reading } \\
\text { Skills } \\
\end{array}$ & $\begin{array}{l}\text { Listening } \\
\text { Skills - } \\
\text { Listening } \\
\text { Skills } \\
\end{array}$ & $\begin{array}{c}\text { Speaking } \\
\text { Skills - } \\
\text { Speaking } \\
\text { Skills } \\
\end{array}$ & $\begin{array}{l}\text { Writing } \\
\text { Skills - } \\
\text { Writing } \\
\text { Skills } \\
\end{array}$ \\
\hline $\mathrm{Z}$ & $-9.976^{\mathrm{b}}$ & $-10.570^{b}$ & $-10.903^{b}$ & $-11.161^{b}$ \\
\hline $\begin{array}{l}\text { Asymp. } \\
\text { Sig. (2- } \\
\text { tailed) }\end{array}$ & 0 & 0 & 0 & 0 \\
\hline \multicolumn{5}{|c|}{ a. Wilcoxon Signed Ranks Test } \\
\hline b. Based & negative ra & & & \\
\hline
\end{tabular}

Table VI: Wilcoxon Analysis presenting Z-value and Significance

The study had focused on analyzing student's perception on diminishing use of CLT approach in ELT and its comparison with to technology-based method. With application of Wilcoxon Signed Ranks test on the pre and post exposure of students to technological teaching aids, there was a substantial difference noted by the students in their language skills. For English reading skills, $Z=-9.976$ indicating significant improvement noticed by students after experiencing technology-based teaching methods. In sync with the English reading skills, English listening skills with $Z=-10.570$, were noted to have positive impact after use of technology-based approaches. Further, it can be noted from the table 3, English speaking skills and English writing skills, were both noted to have $Z=-10.903$ and $Z=-11.161$, i.e., improvement was perceived in post exposure period to technology-based teaching methods. These findings were noted to be in sync with the findings of the previous studies based on this issue wherein Mofareh defined that usage of modern technology in English language teaching helps in providing teaching and learning incentive, encouraging student self-sufficiency, accessing books and publications, effective learning, and better communication [30]. As technology based overcome the existing technology flaws and provide with better learning and communication possibility, thus, use of technology-based method for learning and teaching in case of language skills could help in raising students' commitment to learn a language along with boosting their interest and concentration via improved learning experience.

\section{CONCLUSION}

\section{A. Answering Central Question}

The central research question and its answer are as follows:

1) What is the perception of students on use of CLT approach for learning English language compared with technology based modern methods?

It had been noted in the study that although CLT is very useful method for teaching English language as compared to other traditional methods but now with growing demand for excellent English communication skills, this method had failed to adapt to student's requirement. Use of CLT in ELT had 
diminished as, the method focuses on fluency not on accuracy of grammatical use and pronunciation. This method is not considered fruitful by many students, who are beginners in learning English language and lack of grammatical knowledge make this approach difficult. In addition to this, this approach also has limited engagement with students and does not motivate them to improve their language skill set. Many researchers like Nomass, Ilter, Tabstabei and Gui, and Motteram [6-9] identified the usage of technology in teaching language enhance learner capabilities, provide easy access to learning, contribute in improving skill set of students and support their listening skills. Techniques like video conferencing, talking text, computer assisted language, and digital game-based learning create platform for students to practice gained knowledge. Examination of 200 student's perception also validated this relevance of technology based English learning wherein as the students were shifted from tradition CLT approach to modern technique, their listening, writing, speaking, and reading skills has improved. Thus, use of technology in teaching language had got tremendously good response from both students and teachers, as it cater to the need of every individual learner. The use of technology in learning language had provided learners with a multimedia platform that aids in improving speaking, listing, reading and writing skill of the learner. Use of various technological tools such as, speech-synthesizer, e-dictionaries, audio books, online chatting, educational online games and such more have been noted to gain attention of the students and engage them in learning the language.

\section{B. Implications}

The purpose of this research study was to explore the reasons behind diminishing use of CLT in English language learner and compare the impact of CLT method with other technology-based learning methods upon students' English learning. Assessment of the existing literatures stated that use of technology in language teaching enhances students' language skills by improving their vocabulary, spelling ability, pronunciation, engaging them in listening activities and improves self-study motivation. This study supported the existing researches deductions by having statistical assessment of 200 student's perception. Ch-square test, independent sample t-test, and Wilcoxon analysis also stated that the use of technology-based method for learning and teaching had a significant improvement on language skills of a students as well as had improved students commitment to learn a language along with their interest and engagement. Herein, it was noted that usage of technological tools has improved students' engagement and knowledge retention. Even having better learning experience, mostly students were more satisfied when educators had used technology as compared to CLT. CLT approach is average teaching method thus, the knowledge level of students undergoing this approach-based learning is also of average or beginner level. This approach provides the facility of attaining key learning skills, interactive learning, flexible learning, and independent learning [28]. Thus, students exposed with teaching using technology via better reading, listening, speaking, and writing skills, tend of having improvement in the satisfaction level of students with the teaching mechanism.

\section{Contribution of study}

Technology is bringing about metamorphic changes in the education sector. This study identified that traditional teaching mechanisms like CLT face issues of errors, lack of fluency, low proficiency, and lack of participation of students which tend to hamper the learning experience of students. Thus, this study identifies the benefits of modern technology-based learning mechanisms in the education industry of Saudi Arabia, The study clearly highlights the benefits of communicative language teaching processes by providing an alternative which is much more efficient than traditional one. Further, the study highlights that technological training has become a necessity now-a-days but still is practiced at very low scale. Thus it helps governments and regulatory institutions of the education industry to create quality assurance platforms by promoting the usage of these modern technology based learnings. Lastly, this study helped researchers to gain more knowledge about the shortcomings of practicing traditional learning mechanisms. Hence, this study comparing traditional and modern technology added more clarity in people's perception about the need of moving with technology for more brighter future.

\section{Future Scope}

This study analyzed students' perceptions on CLT approach and its comparison with technology-based teaching methods. This study included a few technological teaching aids such as, Video conferencing, audio CDs, online oral versions, text-tospeech synthesis, interactive books, digital game-based learning and computer assisted language learning. In further studies pedagogical use of different technologies such as textto text synthesizer, speech synthesizing software and other multimedia tools can be analyzed for its assistance in English language teaching and learning. Furthermore, future studies can be based on combining different traditional teaching approaches such CLP, grammar-based methods, audio-lingual methods and such can be combined with appropriate technological tool for enhancing learning of the students. This study had provided only students point of view, educator/instructors perception on this issue can be analyzed in further studies. In addition to this, limitation and perceived drawbacks of using technological tools in language learning can be further explored.

\section{ACKNOWLEDGMENTS}

The author extend their appreciation to the Deputyship for Research \& Innovation, Ministry of Education in Saudi Arabia for funding this research work through the project number "IF 7924-9-3-2018". 


\section{REFERENCES}

[1] M. A. Khan, "EFL Teachers' Perceptions on CLT," Int. J. Res. Innov., vol. 1, 2016.

[2] J. T. Roberts, "The Communicative Approach to Language Teaching: The King is dead! Long live the King!'," Infernafional J. English Sfudies, 2004.

[3] T. H. Mothudi and H. J. Bosman, "Communicative Language Teaching and Learning: Interfacing Theory and Practice - The Case of Botswana Secondary Schools."

[4] T. Dudley-Evans et al., "Cambridge language teaching library The Language Teaching Matrix," 2001.

[5] A. Pop, "The impact of the new technologies in foreign language instruction our experience," Procedia - Soc. Behav. Sci., vol. 2, no. 2, pp. 1185-1189, Jan. 2010, doi: 10.1016/J.SBSPRO.2010.03.169.

[6] B. B. Nomass, "The Impact of Using Technology in Teaching English as a Second Language," English Lang. Lit. Stud., vol. 3, no. 1, 2013, doi: 10.5539 .

[7] B. G. İlter, "How does Technology Affect Language Learning Process at an Early Age?," Procedia - Soc. Behav. Sci., vol. 199, pp. 311-316, Aug. 2015, doi: 10.1016/J.SBSPRO.2015.07.552.

[8] M. Tabatabaei and Y. Gui, "The impact of technology on teaching and learning languages," Educ. a Technol. world Commun. Curr. Emerg. Res. Technol. effort, 2011.

[9] G. Motteram, "The benefits of new technology in language learning | British Council,” 2013. .

[10] E. Cayon, J. S. Correa, and J. A. Sarmiento, "Does quality make a difference for higher education graduates in colombia? Measuring differences in accredited and nonaccredited institutions with similar financial characteristics," WSEAS Trans. Bus. Econ., vol. 17, pp. 859-868, 2020, doi: 10.37394/23207.2020.17.84.

[11]M. M. Batova and V. Baranova Irina, "Information technology knowledge management in the system of interaction of educational and scientific-production structures," WSEAS Trans. Bus. Econ., vol. 16, pp. 545$551,2019$.

[12]K. Bhakta and N. Dutta, "Impact of information technology on teaching-learning process," Int. Res. J. Interdiscip. Multidiscip. Stud., vol. II, no. XI, pp. 131138, 2016, doi: 10.4028/www.scientific.net/AMR.219220.1224 .

[13]H. Basri, "Advantages and disadvantages of communicative language teaching and the improvement methods Schools | Kumpulan Kunci Gitar." .

[14] S. Martin and I. M. Alvarez Valdivia, "Students' feedback beliefs and anxiety in online foreign language oral tasks," Int. J. Educ. Technol. High. Educ., vol. 14, no. 1, p. 18, Dec. 2017, doi: 10.1186/s41239-017-0056-z.

[15] P. McAndrew, S. P. Foubister, and T. Mayes, "Videoconferencing in a language learning application," Interact. Comput., vol. 8, no. 2, pp. 207-217, Jun. 1996, doi: 10.1016/0953-5438(96)01028-4.

[16] M.-Y. Jung, "Videoconferencing Improves Students' Language Learning in the EFL Classroom," TESOL J., vol. 4, no. 4, pp. 743-751, Dec. 2013, doi: 10.1002/tesj.112.
[17]J. Matthews and S. U. Mhuirí, "Using Video Conferencing to Enhance the Teaching and Learning of Target Languages."

[18] O. Watts, "Unsupervised Learning for Text-to-Speech Synthesis," 2012.

[19] S. D. Shyamlee and M. Phil, "Use of Technology in English Language Teaching and Learning : An Analysis," IPEDR, vol. 33, 2012.

[20] T. Bione, J. Grimshaw, and W. Cardoso, "An evaluation of text-to-speech synthesizers in the foreign language classroom: learners' perceptions," 2016, doi: 10.14705/rpnet.2016.eurocall2016.537.

[21] M. Prensky, "Digital game-based learning," Comput. Entertain., vol. 1, no. 1, p. 21, Oct. 2003, doi: $10.1145 / 950566.950596$.

[22]K. Kiili, "Digital game-based learning: Towards an experiential gaming model," Internet High. Educ., vol. 8, 2005, doi: 10.1016/j.iheduc.2004.12.001.

[23] J. Dehaan and W. M. Reed, "The effect of interactivity with a music video game on second language vocabulary recall," vol. 14, no. 2, pp. 74-94, 2010.

[24]A. Chik, "Digital gaming and language learning: autonomy and community," Lang. Learn. Technol., vol. 18, no. 182, pp. 85-100, 2014.

[25] Y.-C. Huang and L.-C. Liao, "A study of text-to-speech (tts) in children's english learning," Teach. English with Technol., vol. 15, no. 1, pp. 14-30.

[26]Z. Handley, "Text-to-Speech Synthesis in ComputerAssisted Language Learning," in The Encyclopedia of Applied Linguistics, Oxford, UK: Blackwell Publishing Ltd, 2012.

[27]C. R. Kothari, Research methodology: methods \&amp; techniques. New Age International (P) Ltd, 2004.

[28] I. Mutambik, "The Role of E-learning in Studying English as a Foreign Language in Saudi Arabia: Students' and Teachers' Perspectives," English Lang. Teach., vol. 11, no. 5, p. 74, 2018, doi: 10.5539/elt.v11n5p74.

[29] A. Mahboob and N. Tilakaratna, "A Principles-Based Approach for English Language Teaching Policies and Practices," TESOL Int. Assoc., no. March, p. 19, 2012.

[30]A. Mofareh, "The Use of Technology in English Language Teaching," Front. Educ. Technol., vol. 2, no. 3, p. p168, 2019, doi: 10.22158/fet.v2n3p168.

\section{Creative Commons Attribution License 4.0 (Attribution 4.0 International, CC BY 4.0)}

This article is published under the terms of the Creative Commons Attribution License 4.0

https://creativecommons.org/licenses/by/4.0/deed.en US 